\title{
Phylogenetic relationships in genus Arachis based on ITS and 5.8S rDNA sequences
}

\author{
Marcelo D Bechara ${ }^{1}$, Márcio C Moretzsohn², Darío A Palmieri ${ }^{3}$, Jomar P Monteiro ${ }^{4}$, Maurício Bacci $\mathrm{Jr}^{5}$, \\ Joaquim Martins $\mathrm{Jr}^{6}$, José FM Valls ${ }^{2}$, Catalina R Lopes ${ }^{4}$, Marcos A Gimenes ${ }^{2^{*}}$
}

\begin{abstract}
Background: The genus Arachis comprises 80 species and it is subdivided into nine taxonomic sections (Arachis, Caulorrhizae, Erectoides, Extranervosae, Heteranthae, Procumbentes, Rhizomatosae, Trierectoides, and Triseminatae). This genus is naturally confined to South America and most of its species are native to Brazil. In order to provide a better understanding of the evolution of the genus, we reconstructed the phylogeny of 45 species using the variation observed on nucleotide sequences in internal transcribed spacer regions (ITS1 and ITS2) and $5.8 \mathrm{~S}$ of nuclear ribosomal DNA.

Results: Intraspecific variation was detected, but in general it was not enough to place accessions of the same species in different clades. Our data support the view that Arachis is a monophyletic group and suggested Heteranthae as the most primitive section of genus Arachis. The results confirmed the circumscriptions of some sections (Caulorrhizae, Extranervosae), but raised questions about others. Sections Erectoides, Trierectoides and Procumbentes were not well defined, while sections Arachis and Rhizomatosae seem to include species that could be moved to different sections. The division of section Arachis into A and B genome species was also observed in the phylogenetic tree and these two groups of species may not have a monophyletic origin. The $2 n=2 x=18$ species of section Arachis (A. praecox, A. palustris and A. decora) were all placed in the same clade, indicating they are closely related to each other, and their genomes are more related to B genome than to the A genome. Data also allowed insights on the origin of tetraploid A. glabrata, suggesting rhizome appeared twice within the genus and raising questions about the placement of that species in section Rhizomatosae.
\end{abstract}

Conclusion: The main clades established in this study in general agreed with many other studies that have used other types of evidences and sets of species, being some of them included in our study and some not. Thus, the relationships established can be a useful framework for future systematic reviews of genus Arachis and for the selection of species to pre-breeding programs.

\section{Background}

The genus Arachis originated in South America, where all the cultivated and wild species are found, and includes 80 described species [1,2]. Groundnut, the allotetraploid species A. hypogaea (genome formula AABB), is the most important species of the genus because it is cultivated as an oilseed crop and as a direct source of human food. The genus also includes species such as $A$. glabrata (section Rhizomatosae) and A. pintoi (section

\footnotetext{
* Correspondence: gimenes@cenargen.embrapa.br

${ }^{2}$ Embrapa Recursos Genéticos e Biotecnologia, C.P. 02372, 70770-917, Brasília, DF, Brazil Full list of author information is available at the end of the article
}

Caulorhizae), which are frequently used in cultivated pastures.

Many studies have focused on the taxonomy of genus Arachis (Table 1). The first published classification divided the genus into six sections, some of which were sub-divided in series [3]. A taxonomic revision of this genus resulted in the inclusion of section Triseminalae [4]. Krapovickas [5] divided the genus into eight sections and classified one of the series of section Erectoides, established by Gregory et al. [4], as a new section called Procumbensae. The genus is currently divided into nine sections (Arachis, Caulorrhizae, Erectoides, Extranervosae, Heteranthae, Procumbentes, Rhizomatosae, Trierectoides, and Triseminatae) based on morphology,
C Biomed Central 
Table 1 Classifications of genus Arachis*

\begin{tabular}{|c|c|c|c|c|c|c|c|}
\hline $\begin{array}{c}\text { Krapovickas } \\
\text { (1969) }\end{array}$ & $\begin{array}{c}\text { Krapovickas } \\
\text { (1975) }\end{array}$ & $\begin{array}{c}\text { Gregory et al. } \\
(1973,1980)\end{array}$ & $\begin{array}{c}\text { Krapovickas } \\
\text { (1990) }\end{array}$ & $\begin{array}{c}\text { Krapovickas } \\
\text { and Gregory } \\
(1994)\end{array}$ & $\begin{array}{c}\text { Number of } \\
\text { described } \\
\text { species }\end{array}$ & $\begin{array}{l}\text { Number of } \\
\text { species } \\
\text { analyzed }\end{array}$ & Genomes \\
\hline \multirow[t]{4}{*}{ AXONOMORPHAE } & ARACHIS & AXONOMORPHAE & ARACHIS & ARACHIS & 31 & 25 & $\begin{array}{c}A, B, D, F, K \\
A B\end{array}$ \\
\hline & & Annuae & Annuae & & & & \\
\hline & & Perennes & Perennes & & & & \\
\hline & & Amphiploides & Amphiploides & & & & \\
\hline \multirow[t]{4}{*}{ ERECTOIDES } & TRIERECTOIDES & ERECTOIDES & ERECTOIDES & ERECTOIDES & 14 & 4 & $\mathrm{E}$ \\
\hline & & Trifoliolatae & Tetrafoliolate & & & & \\
\hline & TETRAERECTOIDES & Tetrafoliolate & Trifoliolatae & TRIERECTOIDES & 2 & 2 & $\mathrm{E}$ \\
\hline & & Procumbensae & PROCUMBENSAE & PROCUMBENTES & 10 & 5 & E \\
\hline CAULORRHIZAE & CAULORRHIZAE & CAULORRHIZAE & CAULORRHIZAE & CAULORRHIZAE & 2 & 2 & C \\
\hline \multirow[t]{3}{*}{ RHIZOMATOSAE } & RHIZOMATOSAE & RHIZOMATOSAE & RHIZOMATOSAE & RHIZOMATOSAE & 2 & 2 & $\mathrm{R}$ \\
\hline & & Prorhizomatosae & Prorhizomatosae & Prorhizomatosae & & & \\
\hline & & Eurhizomatosae & Eurhizomatosae & Eurhizomatosae & & & \\
\hline EXTRANERVOSAE & EXTRANERVOSAE & EXTRANERVOSAE & EXTRANERVOSAE & EXTRANERVOSAE & 10 & 3 & Ex \\
\hline \multirow[t]{2}{*}{ AMBINERVOSAE } & AMBINERVOSAE & PSEUDAXONOMORPHAE & AMBINERVOSAE & HETERANTHAE & 6 & 1 & $\mathrm{Am}$ \\
\hline & & TRISEMINALAE & TRISEMINALAE & TRISEMINATAE & 1 & 1 & $\mathrm{~T}$ \\
\hline
\end{tabular}

*Modified from Valls and Simpson [69].

geographical distribution and crossability [1]. In this last revision, two species with trifoliolate leaves from section Erectoides were transferred to a new section called Trierectoides.

The systematic relationships among Arachis species have been inferred using different molecular markers, such as RAPDs [6], storage proteins $[7,8]$, isozymes $[9,10]$, variation on sequence of desaturase genes [11], RFLP [12], microsatellites [13-16], AFLPs [17], cytogenetic and molecular data from AFLP and the trnT-F plastid region [18], FISH and GISH [19-21]. However, most of these studies included only species belonging to section Arachis. Just recently one study that included species from all sections was published [22].

Understanding the phylogenetic relationships among Arachis species would contribute to the systematics of the genus, comprehension of the origins and evolution of species and sections and the use of species of genus Arachis. For instance, the circumscriptions of some sections are based in criterions that may not reflect phylogenetic relationships. The maintenance of species associated respectively to the $\mathrm{A}$ and the $\mathrm{B}$ genomes of the cultivated peanut in a single section does not seem to be natural and it may be an artificial construction derived from the existence of the peanut, a fixed amphidiploid gathering genetic material from species that when crossed to each other produce unfertile hybrids at the diploid level. Also, section Rhizomatosae, a very important group from the standpoint of forage production, comprises polyploid species (A. glabrata, A. pseudovillosa, A. nitida) and one diploid (A. burkartii) that RAPD [23] and microsatellite data [24] showed to be very distinct from the other species in this section. As mentioned before, phylogenetic information will also have great impact in the utilization of the species, mainly those from sections that comprise cultivated species. For instance, for many years A. batizocoi was considered the donor of the B genome of $A$. hypogaea and that species was used with moderated success in prebreeding programs. However, molecular and cytogenetic evidences showed that $A$. ipaënsis was the most probable donor of $\mathrm{B}$ genome of $A$. hypogaea and $A$. duranensis the donor of the A genome [25]. That information was corroborated based on molecular cytogenetics [19] and crossability [26]. The number of accessions of $A$. duranensis is very large [1] comprising large variability that could be used to improve A. hypogaea through introgression into its A genome. Besides, the relationships between A genome species are well defined and they show very good crossability to each other [1]. On the other hand, there is an unique accession of A. ipaënsis available and the relationships among species of section Arachis that do not have the A genome is not well defined. The non A genome species group is very diverse comprising species with different degrees of affinity to the B genome of A. hypogaea [18,27]. Phylogeny and genomic data also allow a better understanding of the evolution in section Arachis. For instance, recently the first comparative genomic study between the genomes of A. hypogaea using microsatellite markers and two map populations resulting from crosses between two A genome species and two $\mathrm{B}$ genome species was published [28]. The comparison between the B genome and $\mathrm{A}$ genome maps revealed a high degree of synteny. 
The development of genetic maps for Arachis diploid wild species with $\mathrm{A}$ and $\mathrm{B}$ genomes associated to phylogenetic studies effectively is a significant advance towards the construction of a transferable reference map for Arachis.

The DNA sequence variation observed in the internal transcribed spacers (ITS1 and ITS2) of nuclear rDNA, located between the $18 \mathrm{~S}$ and $26 \mathrm{~S}$ rDNA coding regions, has been largely used for phylogenetic analysis at plant genus and species discrimination levels [29-34]. The sequences are relatively easy to align because few length variations have been observed at the genus level in flowering plants, they are long enough to offer a sufficient number of potential characters for phylogenetic reconstruction, and are flanked by regions that are highly conserved within genera, thus simplifying the isolation and sequencing of the region through the use of universal primers [35].

The objective of this work was to establish the phylogenetic relationships among species of the genus Arachis. The polymorphism in sequences of internal transcribed spacers ITS1 and ITS2 and 5.8 S rDNA coding region was used to determine relationships among 45 species of genus Arachis.

\section{Results and Discussion}

We have analyzed 55 accessions encompassing 45 Arachis species and the nine taxonomical sections. Consensus sequences were obtained for each accession using four to ten reads. The number of reads per accession varied because their quality also varied. For some species only four reads were necessary to get a good quality consensus sequence and for some ten reads were necessary.

In spite of the large number of studies using ITS to infer phylogeny in a very large number of genus and families, some authors have criticized the use of these genomic regions. ITS data may cause incongruence due to the various mechanisms that can influence ITS variation [33]. Among the most prevalent complications for phylogenetic inference is the existence in many plant genomes of extensive sequence variation, arising from ancient or recent array duplication events, genomic harboring of pseudogenes in various states of decay, and/or incomplete intra- or interarray homogenization [32]. Despite that, we have used ITS region to infer phylogeny in genus Arachis and, to have insights in how much the variation in this region may have interfered in the species relationship establishment, we included more than one individual from six species (A. pintoi: two accessions; $A$. major: two accessions; $A$. paraguariensis: two accessions; $A$. magna: two accessions, $A$. kuhlmannii: four accessions, $A$. hoehnei: three accessions). We also included species that are very related to each other based on different types of evidences, such as A. hypogaea and $A$. monticola $[12,16,36]$ and $A$. repens and $A$. pintoi $[37,38]$ and included groups of species whose high affinity was demonstrated by many different methods, such as the A genome species [21].

As it can be seen in Figure 1, there was variation between accessions of the same species which may have been caused by the ITS variation cited above. The variation found for three species (A. pintoi, A. major, $A$. hoehnei) was not enough to place their accessions away from each other. Arachis magna accessions were not placed together but they were in the same clade. Arachis paraguariensis and $A$. kuhlmannii accessions were, in general, placed away from each other.

The two accessions of $A$. paraguariensis analyzed belong to different subspecies (A. paraguariensis subsp. paraguariensis and $A$. paraguariensis subsp. capibarensis). The differentiation between these two subspecies based on morphology is very difficult but they are considered as different subspecific taxa based on their distinct geographic distribution [1] and SAT chromosome morphology [39].

Four accessions of $A$. kuhlmannii were analyzed (VPoBi 9375 - A. kuhlmannii 1; VSGr 6404 - A. kuhlmannii - 2; VPzRcSgSv 13530 - A. kuhlmannii 3; VSPmSv 13721 - A. kuhlmannii 4). All of them were placed in the A genome clade, but into three different subclades. Arachis kuhlmannii 1 and 2 were placed close to each other in a clade that also included $A$. helodes and A. linearifolia. Arachis kuhlmannii 3 was placed in a subclade with $A$. hypogaea, A. correntina, $A$. microsperma, A. schininii and A. villosa, while $A$. kuhlmannii 4 in a clade with $A$. cardenasii, A. simpsonii, $A$. monticola and A. duranensis. Accessions of A. kulhmannii were also placed in different subclusters based on microsatellite and AFLP data $[16,17]$. In a dendrogram obtained using RAPD data, A. kuhlmannii 1, 2 and 4 grouped together and A. kuhlmannii 3 was placed in a different group that comprised accessions from Mato Grosso do Sul State in Brazil [40]. Arachis kuhlmannii 4 was collected in Brazil near the frontier with Bolivia, and probably is more distinct from the other $A$. kuhlmannii accessions and more related to $A$. cardenasii. In the RAPD dendrogram, $A$. kuhlmannii 4 grouped to $A$. simpsonii accession VSPmSv 13728, which was collected in Bolivia, in the same population where the species typus was collected.

Thus, the placement of $A$. paraguariensis and A. kuhlmannii accessions may have been due to factors not related exclusively to the variation found in ITS regions since our data corroborates previous studies demonstrating high variability within these species.

The closely related allopolyploid species $A$. hypogaea and $A$. monticola were placed in different clades. It is 


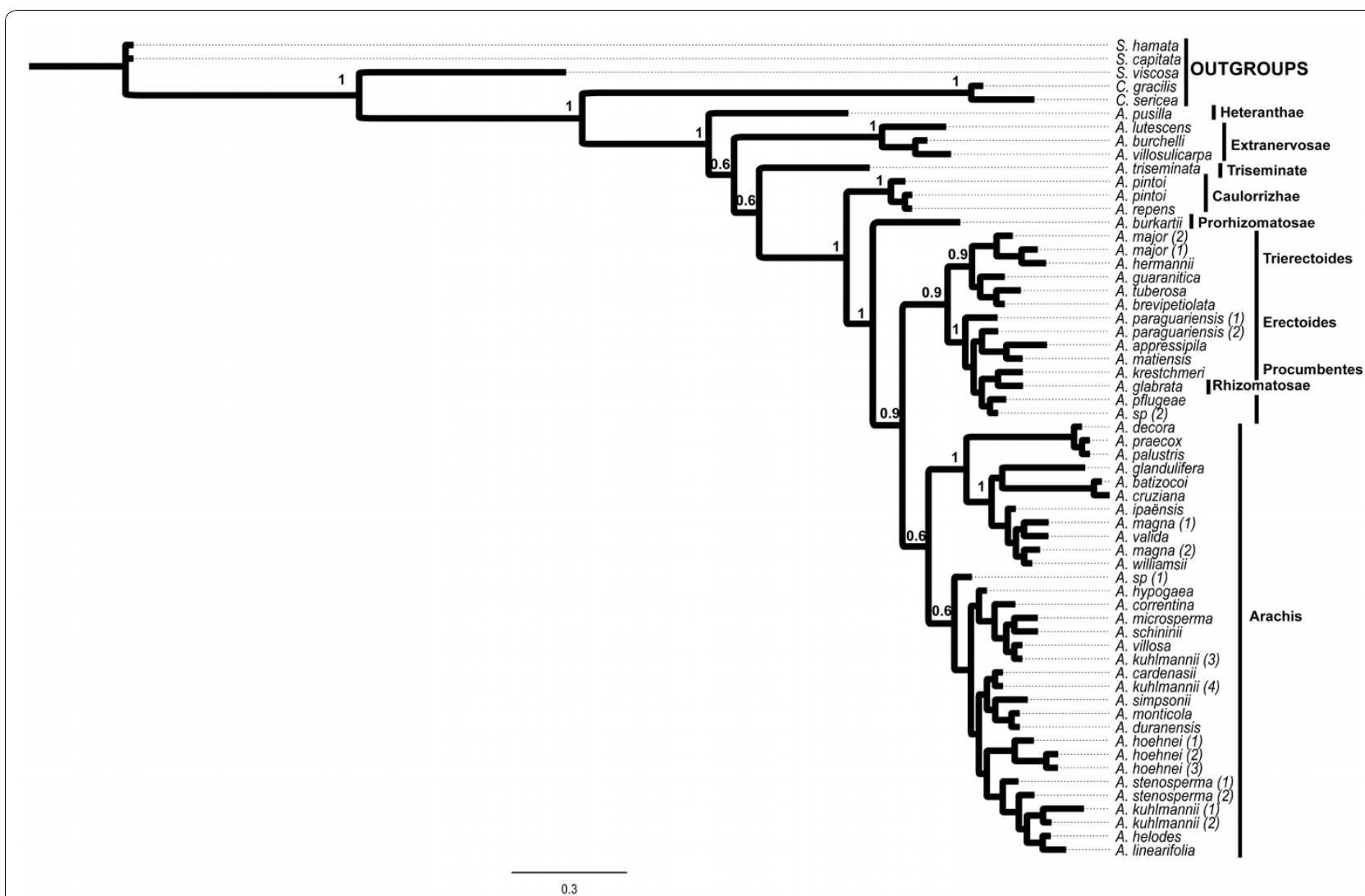

Figure 1 Phylogenetic tree obtained from Bayesian Inference Analysis. Numbers ahead nodes are the posterior probabilities support values. Three branchs are proportional to mutational events sampled in sequences alignment.

known that $A$. monticola is the closest related species to A. hypogaea [1]. Despite that, A. monticola was considered as a distinct species from A. hypogaea [1]. However, some doubts about its classification still remain, because this species has a high crossability with A. hypogaea $[1,41]$. It is also an allotetraploid and both species have identical genomes $[19,36,39]$. Furthermore part of their geographic distribution overlaps [1]. Molecular marker data also confirmed the very close genetic relationship between these two species $[6,11,13,15,17,42,43]$. In our case, despite the causes of variation in ITS regions, the observed placement of $A$. hypogaea and $A$. monticola was certainly influenced by the fact that these species have ITS regions from A and B genomes which our results showed to be different and seem to be specific for each genome type found in genus Arachis. The sequences of $A$. hypogaea and $A$. monticola included in this study represent one of the genomes and may even be a mixture of the sequences from both. As mentioned above the close relationships between these two species have been demonstrated using different evidences. Thus, our data is limited to infer phylogenetic relationships between the allopolyploids as well as their relationships to the wild diploid species.
Section Heteranthae showed a basal position, followed by Extranervosae, Triseminatae, Caulorrhizae, and Rhizomatosae Ser. Prorhizomatosae, Procumbentes/Trierectoides/Erectoides/Rhizomatosae and Arachis. Despite the lack of dating analysis, the position of clades in relation to the outgroups agreed with DNA content analysis showing that species with greater DNA content were included in sections believed to have a more recent origin (Procumbentes, Caulorrhizae, Rhizomatosae and Arachis), whereas those with lower DNA content in the most primitive or ancient sections (Extranervosae, Heteranthae and Triseminatae) [44]. Sections Extranervosae, Heteranthae and Triseminatae are believed to be among the oldest sections in genus Arachis based on their affinity with genus Stylosanthes [1].

\section{Section circumscriptions}

The results confirmed the circumscriptions of sections Caulorrhizae and Extranervosae and suggested some sections may not be natural groups. The circumscriptions of sections Erectoides, Trierectoides and Procumbentes were not well defined, suggesting that these three sections could be grouped in one or two sections. On the other hand, our data suggested sections Arachis and 
Rhizomatosae could be divided into two new sections each.

Sections Trierectoides, Erectoides and Procumbentes seem to be a monophyletic group. Species from these sections were distributed in two sub-clades. One of them comprised three species of section Erectoides (A. major, $A$. hermannii and $A$. brevipetiolata) and two species of section Trierectoides (A. guaranitica and $A$. tuberosa). Arachis brevipetiolata was more related to Trierectoides than to the other two species of Erectoides. The other sub-clade comprised one species of section Erectoides (A. paraguariensis), four species of section Procumbentes (A. appressipila, A. kretschmeri, A. matiensis, A. pflugeae, and $A$. sp. 2) and one species of section Rhizomatosae (A. glabrata). As can be seen in Table 1, species from sections Trierectoides, Erectoides and Procumbentes were all put together in the same section for many years and after three taxonomic revisions of genus Arachis. Only in 1990, some species were put in a new section called Procumbensae that is the actual Procumbentes section. Our data supported the first classification [3].

Section Arachis comprises species of three types of genomes (A, B and D). The crossability and inter-specific hybrid fertility between A genome species and between some $B$ genome species are very high $[12,18]$. However, crosses between $\mathrm{A}$ and $\mathrm{B}$ genome species result in unfertile hybrids [1]. The cultivated peanut is fertile just because it had its chromosomes duplicated, having a diploid-like meiosis, with no pairing of chromosomes from different genomes. Thus, based on the use of crossability for the establishment of the taxonomic sections it may be considered that, if the peanut have not evolved, most Arachis specialists would certainly assign the A genome and $\mathrm{B}$ genome species to distinct sections.

The presence of rhizomes is the main reason for a species to be in section Rhizomatosae, which comprises three polyploidy species (A. glabrata, A. pseudovillosa, A. nitida) and one diploid (A. burkartii). RAPD [23] and microsatellite data [24] showed that the diploid species is very distinct from the other species of this section. The different ploidy levels and variation in the ITS could result in the misplacement of $A$. glabrata or $A$. burkartii. However, we observed in section Arachis, which also includes diploid and polyploidy species that ITS variation may result in some unexpected placement of species, but that is not enough for their placement in clades of different sections.

Sections Triseminatae and Heteranthae had just one species analyzed but they were placed in the tree in individual branches suggesting these sections are also natural groups. Arachis burkartii had a placement very similar to those species from sections Triseminatae and
Heteranthae. Thus, based on ours and previous data $[23,24]$ the establishment of a new section for $A$. burkartii should be considered.

\section{Section Arachis}

The two genomes presented in domesticated peanut differ by one striking feature: one of the genomes (A) has a pair of chromosomes, called $\mathrm{A}$, which is conspicuously smaller than the other chromosomes, while the other genome lacks this small chromosome [25]. The species of section Arachis are therefore classified as having A or $B$ genomes based on the presence or absence of the $A$ pair. A third genome was identified in the genus, the D genome, which is only found in A. glandulifera [45].

The species of section Arachis were placed in two clades. The first one was divided into sub-clades. The first sub-clade comprised A. hoehnei $(1,2,3)$, A. stenosperma (1,2), A. kuhlmannii (1,2), A. helodes and $A$. linearifolia; the second $A$. cardenasii, A. kuhlmannii (4), A. simpsonii, A. monticola and $A$. duranensis and the third comprised A. hypogaea, A. correntina, A. microsperma, A. schininii, A. villosa and A. kuhlmannii (3). Arachis sp (1) was very related to the A genome species but it was not included in any of the above clades. The second clade of section Arachis species was divided into two sub-clades. The first included $2 \mathrm{n}=2 \mathrm{x}=20$ species and the other, species with $2 \mathrm{n}=2 \mathrm{x}=18$ (A. decora, $A$. praecox and $A$. palustris). The species with $2 \mathrm{n}=20$ were separated into two sister subclades, one of them being formed only by B genome species (A. magna, A. valida, A. ipaënsis and $A$. williamsii) and the other included $A$. batizocoi (B genome), $A$. cruziana (B genome) and $A$. glandulifera (D genome). Arachis batizocoi and A. cruziana were very recently described as having a $\mathrm{K}$ genome based on FISH mapping of rDNA loci and heterochromatin detection [21].

The first clade of section Arachis included all the A genome species and $A$. hoehnei. It was believed that $A$. hoehnei did not present the small "A" chromosome pair [39]. Arachis hoehnei also grouped to A genome species based on the polymorphism of trnT-F region [18] and RAPD markers [27], but grouped to other B genome species based on microsatellite markers [13], and to the aneuploid $(2 \mathrm{n}=18)$ species with AFLP markers [18]. In our study, three different accessions of this species were included in the analysis and all of them were placed close to the A genome species, confirming that this species was correctly placed on the phylogenetic tree. The cytogenetical analysis of $A$. hoehnei was recently re-done and it was verified that this species has the A chromosome pair [21]. Thus, our data suggested A genome species are monophyletic.

The second clade comprised all species of section Arachis that do not have the A chromosome pair. This 
clade included the $2 n=20$ species that are classified as $\mathrm{B}$ genome species and the ones that possess $2 \mathrm{n}=18$ chromosomes (A. decora, A. palustris, and A. praecox). The $2 \mathrm{n}=2 \mathrm{x}=18$ species lack the small pair of chromosomes characteristic of the A genome species [46]. Lavia [47] suggested that $A$. palustris was derived from a species with $x=10$ chromosomes and these species are phylogenetically related to the $\mathrm{B}$ genomes. Analyses based on AFLP [18] and microsatellite [48] data placed those $2 \mathrm{n}=2 \mathrm{x}=18$ species closely to A genome species. However, microsatellite markers [13] and sequencing of the trn T-F region [18] and also our data showed those species are more closely related to $\mathrm{B}$ genome species. Thus, our study corroborates previous ones $[13,18]$ and suggested these species originated from B genome species.

As mentioned above, the non A genome species from section Arachis with 2n = 20 chromosomes were placed in two clades. Molecular evidences based on markers such as RFLPs [42,49], RAPD [6,50], AFLP [17], and microsatellites [48] suggested that section Arachis diploids lacking the small A chromosome pair comprise a very diverse group, of which A. ipaënsis, A. magna, A. williamsii, and $A$. valida, closely linked in the present analysis, plus $A$. gregoryi [12] are those more closely associated to the $\mathrm{B}$ genome of $A$. hypogaea/A. monticola. Hybrids between $A$. ipaënsis and A. magna have shown $84 \%$ viable pollen [1]. Other kinds of evidences, such as molecular $[6,28,43]$ and morphological [51] data, showed that these two species are closely related. Crossings between $A$. williamsii and A. ipaënsis resulted in hybrids with $66.9 \%$ of pollen stainability [52]. If the latter is the donor of the $\mathrm{B}$ genome to A. hypogaea [25], our data suggest that $A$. ipaënsis, $A$. williamsii, A. magna and $A$. valida could be used for the improvement of the $B$ genome of cultivated peanut. This would increase the variability available for this purpose since a single accession of $A$. ipaënsis is available.

Arachis batizocoi was very close related to $A$. cruziana. Arachis batizocoi is considered a good genetic bridge to transfer genes to cultivated peanut [53,54]. If the phylogenetic relationships were correlated with the crossability, as observed among the A genome species [55,56], A. cruziana would have some crossability with $A$. batizocoi and could also be used as bridge for gene introgression in $A$. hypogaea. In fact, $\mathrm{F}_{1}$ hybrids between these two species had $36.4 \%$ of pollen viability (male fertility) and 0.3 I (univalents) and 9.9 II (bivalents) [18]. Thus, our data suggested that $A$. cruziana also can be a source of genes to $A$. hypogaea since it is very related to A. batizocoi.

Arachis glandulifera is classified as D genome since it does not cross with $A$. hypogaea and it has the most asymmetrical karyotype in genus Arachis [45]. Arachis glandulifera, like the B genome species, does not show the small pair of chromosomes found in the A genome species. Isoenzyme [10], RFLP [42], RAPD [6], AFLP [18] and cytogenetical [57] data also showed that $A$. batizocoi and $A$. glandulifera were closely related. Our data suggest that $A$. glandulifera may be derived from a $\mathrm{B}$ genome ancestor species.

Through the analysis of the heterochromatic bands and $45 \mathrm{~S}$ rDNA loci patterns, the species previously classified as $\mathrm{B}$ genome were arranged into three groups called B (A. ipaënsis, A. magna, A. gregoryi, A. valida and $A$. williamsii), K (A. batizocoi, A. cruziana, and $A$. krapovickasii) and F (A. benensis and A. trinitensis) [21]. Our data supported the classification in B and $\mathrm{K}$ genomes. We have not analyzed species of the new $F$ genome.

\section{Sections Trierectoides, Erectoides and Procumbentes}

As mentioned before the circumscriptions of these three sections were not clear and because of that their results were presented and discussed together. Our results agreed with the classification proposed by Krapovickas [3] which had all species from those three sections in only one section, called Erectoides. The data partially agreed also to a more recent classification proposed by the same author [5], that divided section Erectoides in two sections (Erectoides and Procumbensae), since as it can be seen in Figure 1, species of Erectoides and Trierectoides were all in a same sub-clade and species of Procumbentes were placed all together with $A$. paraguariensis and A. glabrata.

Arachis paraguariensis shows low genetic affinity to the other species of section Erectoides and because it shows some morphological peculiarities in the root, flowers and fruits it was suggested that this species should be segregated in an independent section [1]. Our results also raised doubt about the classification of this species, and suggested that $A$. paraguariensis might be classified as belonging to section Procumbentes. The segregation of $A$. paraguariensis from other Erectoides species was also observed in phylogeny based on ITS data using parsimony analysis [22].

The placement of $A$. glabrata in a clade with Procumbentes and Erectoides species will be discussed in the section Rhizomatosae item.

The clade formed by sections Erectoides, Trierectoides and Procumbentes was the most related to section Arachis. Crossability data between members of sections Arachis and Erectoides suggest that these two sections are more phylogenetically related to each other than to the other sections of the genus since pollination has lead to fertilization. Although there has been no development of the resulting proembryos [58], members of the other sections do not even show such a degree of 
success on crossings with section Arachis [55]. Isozyme and protein pattern data $[8,10]$ suggested that section Erectoides and Procumbentes are closely related to the section Arachis.

\section{Section Caulorrhizae}

The morphological traits that have been traditionally used to distinguish the two type specimens of $A$. pintoi (GK 12787) and A. repens (GKP10538) are not sufficient to differentiate all the accessions collected, as they show intermediate phenotypes between the extreme types [59].

The clade was formed by the two species of section Caulorrhizae, confirming that A. pintoi and A. repens are very closely related. There were no differences between the sequences of $A$. pintoi (CIAT $22237=$ W132) and $A$. repens (V 5868), and few differences of these two in relation to accession V 6791, also considered as $A$. pintoi. RAPD data also suggested they are very closely related [37]. $\mathrm{F}_{1}$ hybrids between accession GK 12787 of $A$. pintoi and accession GKP 10538 of $A$. repens, which represent the extreme types, had $86.8 \%$ pollen fertility [55], which is higher than the level of pollen fertility found in intraespecific hybrids of crosses between accessions of some other Arachis species $[45,60]$.

\section{Section Triseminatae}

The phylogenetic data showed that $A$. triseminata was not closely related to species of any other sections, in agreement with its placement in a separate section (Triseminatae) [1]. No successful crossings among A. triseminata and members of other sections were obtained $[1,55]$, showing its genetic isolation from other sections of genus Arachis.

\section{Section Heteranthae}

Arachis pusilla, the only species of section Heteranthae included in this study, had a basal position, on the first radiation of genus Arachis (Figure 1) and closely related to Extranervosae, which formed the second radiation in the genus. The affinity of Heteranthae and Extranervosae sections agreed with floral morphology, geographical distribution and crossability data, since the only known intersectional hybrid of Extranervosae was obtained from a cross with Heteranthae [1].

\section{Section Rhizomatosae}

Cytogenetic data suggested that the origins of Arachis tetraploid species (A. glabrata and A. hypogaea) were independent [61]. An analysis using RFLP markers also showed that $A$. glabrata was very distinct from A. hypogaea [49]. In the present study, A. glabrata and $A$. hypogaea were placed in different clades, confirming that the polyploid species evolved independently in the genus.

Arachis glabrata was more related to species of section Procumbentes than to A. burkartii which is also traditionally allocated in section Rhizomatosae, although in a series of its own. These species differed on the ploidy level, since A. glabrata is a tetraploid $(2 \mathrm{n}=4 \mathrm{x}=40)$ and $A$. burkartii a diploid species. Crossings between $A$. glabrata and diploid species from other sections resulted in hybrids, in contrast to $A$. burkartii, for which no hybrids were obtained from numerous attempted crosses [55]. The other tetraploid species analyzed ( $A$. hypogaea) was placed close to diploid species that have similar genomes and are certainly involved in its origin $[1,25]$. Thus, the data indicated that the referred species of section Rhizomatosae did not have a monophyletic origin.

Arachis glabrata was placed in a clade with species from section Erectoides and Procumbentes. Tetraploid species of section Rhizomatosae were classified as EERR [55], and at that time the EE crossing group was attributed to section Erectoides, which comprised all species that, according to the last classification [1], are distributed in sections Procumbentes, Erectoides and Trierectoides. Thus, based in our and previous data we suggested the following hypothesis to the origin of $A$. glabrata: 1) A. glabrata originated from species of the Erectoides group, with rhizomes appearing twice, independently, in the evolution of genus Arachis; 2) A. glabrata is an allopolyploid EERR, as previously suggested [55], that resulted from a cross between one species from section Erectoides and one species from section Rhizomatosae, that had a genome not similar to the one found in A. burkartii.

\section{Conclusion}

The main clades established in this study in general agreed with many other studies that have used other types of evidences (morphological, crossability, biochemical, cytogenetical and molecular) and different species, being some of them included in our study and some not. Thus, the relationships established do reflects the affinity of the species, and that can be a useful framework for future systematic reviews of genus Arachis and for the selection of species to prebreeding programs.

\section{Methods}

\section{Plant material}

A total of 55 accessions, which represent 45 species and the nine sections of the genus Arachis were analyzed (Table 2). These accessions were obtained from the 
Table 2 Accessions of genus Arachis analyzed in this study

\begin{tabular}{lccc}
\hline Species & Accession & $\begin{array}{c}\text { Genome }{ }^{1} \\
\begin{array}{c}\text { Chromosome } \\
\text { number/ } \\
\text { Ploidy level }^{2}\end{array}\end{array} \begin{array}{c}\text { GenBank Accession } \\
\text { Numbers }\end{array}$ \\
\hline
\end{tabular}

\section{Sect. Arachis}

A. cardenasii Krapov. \& W.C.Greg.

A. correntina (Burkart) Krapov. \& W.C.Greg.

A. duranensis Krapov. \& W.C.Greg.

A. helodes Mart. ex Krapov. \& Rigoni

A. kuhlmannii (1) Krapov. \& W.C.Greg.

A. kuhlmannii (2)

A. kuhlmannii (3)

A. kuhlmannii (4)

A. sp (1)

A. linearifolia Valls, Krapov. \& C.E.Simpson

A. microsperma Krapov., W.C.Greg. \& Valls

A. schininii Krapov., Valls \& C.E.Simpson

A. simpsonii Krapov. \& W.C.Greg.

A. stenosperma (1) Krapov. \& W.C.Greg.

A. stenosperma (2)

A. villosa Benth.

A. hypogaea $\mathrm{L}$.

A. monticola Krapov. \& Rigoni

A. batizocoi Krapov. \& W.C.Greg.

A. cruziana Krapov., W.C.Greg. \& C.E.Simpson

A. hoehnei (1) Krapov. \& W.C.Greg.

A. hoehnei (2) Krapov. \& W.C.Greg.

A. hoehnei (3) Krapov. \& W.C.Greg.

A. ipaënsis Krapov. \& W.C.Greg.

A. magna (1) Krapov., W.C.Greg. \& C.E.Simpson

A. magna (2)

A. williamsii Krapov. \& W.C.Greg.

A. valida Krapov., \& W.C.Greg.

A. glandulifera Stalker

A. decora Krapov., W.C.Greg. \& Valls

A. palustris Krapov., W.C.Greg. \& Valls

A. praecox Krapov., W.C.Greg. \& Valls

Sect. Erectoides Krapov. \& W.C.Greg.

A. brevipetiolata Krapov. \& W.C.Greg.

A. hermannii Krapov. \& W.C.Greg.

A. major (1) Krapov. \& W.C.Greg.

A. major (2)

A. paraguariensis Chodat \& Hassl. (1) subsp. capibarensis Krapov. \& W.C.Greg.

A. paraguariensis (2) subsp. paraguariensis Chodat \& Hassl.

Sect. Trierectoides Krapov. \& W.C.Greg.

A. guaranitica Chodat \& Hassl.

A. tuberosa Bong. ex Benth
GKP 10017

CIAT 22249

VNvEc 14167

VSGr 6325

VPoBi 9375

VSGr 6404

VPzRcSgSv 13530

VSPmSv 13721

VSPmSV 13736

VPoBi 9401

VRGeSv 7681

VSW 9923

VSPmSV 13728

Lm 1

VSPmW 13844

VGoMrOv 12812

Mf 1560

VOa 14165

K 9484

WiSVg 1302

KG 30006

VPoBi 9146

VPoBi 9140

KGBPSSC 30076

KGSSC 30097

VSPmSv 13760

WiDc 1118

VPoBi 9153

VSPmSv 13738

VSPmPzRs 13290

VPmSv 13023

VSGr 6416

VMPzW 13959

VPoJSV 10390

VRGeSv 7644

VRGeSv 7632

VMPzW 14024

VRGeSv 7677

VRcSgSV 13600

VRGeSv 7607
$2 \mathrm{n}=2 \mathrm{x}=20$

AY615236

$2 n=2 x=20$

AF203554

$2 \mathrm{n}=2 \mathrm{x}=20$

AY615240

$2 \mathrm{n}=2 \mathrm{x}=20$

AY615241

$2 n=2 x=20$

AY615232

$2 n=2 x=20$

$2 n=2 x=20$

$2 \mathrm{n}=2 \mathrm{x}=20$

$2 n=2 \mathrm{x}=20$

$2 n=2 x=20$

$2 n=2 x=20$

$2 n=2 x=20$

$2 \mathrm{n}=2 \mathrm{x}=20$

$2 n=2 x=20$

$2 n=2 x=20$

$2 \mathrm{n}=2 \mathrm{x}=20$

$2 \mathrm{n}=4 \mathrm{x}=40$

$2 \mathrm{n}=4 \mathrm{x}=40$

$2 \mathrm{n}=2 \mathrm{x}=20$

$2 n=2 x=20$

$2 \mathrm{n}=2 \mathrm{x}=20$

$2 n=2 x=20$

$2 n=2 x=20$

$2 n=2 x=20$

$2 n=2 x=20$

$2 n=2 x=20$

$2 n=2 x=20$

$2 n=2 x=20$

$2 n=2 x=20$

$2 \mathrm{n}=2 \mathrm{x}=18$

$2 n=2 x=18$

$2 n=2 x=18$

Unknown
AY615219

AY615238

AY615243

AY615226

AY615242

AY615221

AY615248

AY615247

AY615252

AY615227

AY615215

AY615267

AY615239

AY615256

AY615259

AY615223

AY615224

AY615222

AY615257

AY615230

AY615231

AY615255

AY615244

AY615258

AY615237

AY615238

AY615234

AY615251

AY615260

AY615229

AY615228

AY615217

AY615218

Sect. Procumbentes Krapov. \& W.C.Greg.

A. appressipila Krapov. \& W.C.Greg. 
Table 2 Accessions of genus Arachis analyzed in this study (Continued)

\begin{tabular}{lllll}
\hline A. kretschmeri Krapov. \& W.C.Greg. & KrRy s/n (IRFL & E & $2 n=2 x=20$ & AY615220 \\
& 2273) & & & \\
A. matiensis Krapov., W.C.Greg. \& C.E.Simpson & VSPmSV 13718 & $E$ & $2 n=2 x=20$ & AY615249 \\
A. pflugeae C.E.Simpson, Krapov. \& Valls & VRcSgSV 13589 & E & $2 n=2 x=20$ & AY615233 \\
A. sp (2) & VMPzW 14044 & E & $2 n=2 x=20$ & AY615225
\end{tabular}

Sect. Rhizomatosae Krapov. \& W.C.Greg.

Ser. Prorhizomatosae Krapov. \& W.C.Greg.

\begin{tabular}{|c|c|c|c|c|}
\hline A. burkartii Handro & VZnMrOvW 12322 & $\mathrm{R}$ & $2 n=2 x=20$ & AY615245 \\
\hline er. $R$ & & & & \\
\hline A. glabrata var. glabrata Benth. & Cv. Florigraze & $\mathrm{R}$ & $2 n=4 x=40$ & AY615250 \\
\hline
\end{tabular}

A. glabrata var. glabrata Benth.

Cv. Florigraze

$$
2 n=4 x=40
$$

AY615250

Sect. Caulorrhizae Krapov. \& W.C.Greg.

A. pintoi Krapov. \& W.C.Greg. (1)
A. pintoi (2)

A. repens Handro

Sect. Triseminatae Krapov. \& W.C.Greg.

A. triseminata Krapov. \& W.C.Greg.

Sect. Heteranthae Krapov. \& W.C.Greg.

A. pusilla Benth.

Sect. Extranervosae Krapov. \& W.C.Greg.
A. burchellii Krapov. \& W.C.Greg.
VGaRoSv 12618
VSStGdW 7741
VKSSV 8816
A. lutescens Krapov. \& Rigoni
A. villosulicarpa Hoehne

$\begin{array}{lll}C & 2 n=2 x=20 & \text { AY615263 } \\ \text { C } & 2 n=2 x=20 & \text { AF203551 } \\ \text { C } & 2 n=2 x=20 & \text { AY615264 }\end{array}$

W 195

$\mathrm{T}$

$2 n=2 x=20$

AY615253
AM

$2 n=2 x=20$
$2 \mathrm{n}=2 \mathrm{x}=20$

$2 \mathrm{n}=2 \mathrm{x}=20$

$2 n=2 x=20$

EX

$\begin{array}{lll}\text { EX } & 2 n=2 x=20 & \text { AY615262 } \\ \text { EX } & 2 n=2 x=20 & \text { AY615246 } \\ \text { EX } & 2 n=2 x=20 & \text { AY615265 }\end{array}$

\section{Outgroups}

Chapmannia gracilis Balf.f Thullin

Chapmannia sericea: Thulin \& Mc Kean

Stylosanthes capitata Vogel

Stylosanthes hamata

Stylosanthes viscosa SW.

Collectors: B = D.J.Banks; Bi = L.B.Bianchetti; Dc = D. Claure; Ec = E.D.Cruz; G = W.C.Gregory; Ga = M.L.Galgaro; Gd = I.J.Godoy; Ge = M.A.N.Gerin; Go = K.E.Gomes; $\mathrm{Gr}=\mathrm{A}$.Gripp; J = L.Jank; $\mathrm{K}=$ A.Krapovickas; $\mathrm{Kr}=$ A.Kretschmer Jr.; $\mathrm{Lm}=$ L.Monçato; $\mathrm{M}=$ J.P.Moss; $\mathrm{Mf}=$ Est.Exp.Agr. Manfredi, Córdoba, Argentina; $\mathrm{Mr}=\mathrm{C}$.O.C. Moraes; Nv = L.Novara; Oa = O.Ahumada; Ov = J.C.Oliveira; P = J.Pietrarelli; Pm = R.N.Pittman; Po = A.Pott; Pz = E.A.Pizarro; R = V.R.Rao; Rc = R.C.Oliveira; Ro = D. M.S.Rocha; Rs = R.C.Santos; Ry = P.R.Rayman; S = C.E.Simpson; Sa = J.M.Santos; Sc = A. Schinini; Sg = A.K.Singh; St = H.T.Stalker; Sv = G.P.Silva; V = J.F.M.Valls; Vg $=$ I.Vargas; $\mathrm{W}=$ W.L.Werneck; $\mathrm{Wi}=$ D.E.Williams; $\mathrm{Zn}=$ A.Zanin

1 - Genome designations follow abreviations proposed by Smartt \& Stalker [61] for taxonomic sections and group of species in section Arachis [53].

2 - Chromosome numbers are the observed for each species and compiled by Fernández \& Krapovickas [39], Lavia \& Fernández [44], Lavia et al [46,70]. Eventually, counts were obtained by the accessions listed.

Brazilian Arachis Germplasm Collection, maintained at Embrapa Recursos Genéticos e Biotecnologia - CENARGEN (Brasília-DF, Brazil). All plants were grown from seed or cuttings (sections Rhizomatosae and Caulorrhi$z a e)$ under greenhouse conditions prior to DNA extraction. Stylosanthes capitata, S. hamata, S. viscosa, Chapmannia gracilis and C. sericea were used as outgroups, because these genera are considered to be closely related to Arachis $[1,30,31,62]$.

\section{DNA extraction and PCR amplification}

DNA was extracted from young leaflets of single plants, using a procedure previously described [63]. Primers ITS5 (5'GGAAGTAAAAGTCGTAACAAGG3') and 
ITS4 (5'TCCTCCGCTTATTGATATGC3') were used to amplify the two internal transcribed regions, ITS1 and ITS2, and the 5.8 S gene [64]. Each amplification reaction contained $12 \mu \mathrm{l}$ of water, $1.5 \mu \mathrm{l}$ of magnesium chloride $(50 \mathrm{mM}), 2.6 \mu \mathrm{l}$ of $10 \times \mathrm{Taq}$ polymerase reaction buffer, $1.5 \mu \mathrm{l}$ of each primer $(10 \mathrm{mM}), 5.0 \mu \mathrm{l}$ of a $5 \mathrm{ng} / \mu \mathrm{l}$ DNA dilution, $2.2 \mu \mathrm{l}$ of dNTPs $(2.5 \mu \mathrm{M}$ each $)$ and $0.2 \mu \mathrm{l}$ of Taq DNA polymerase $(5 \mathrm{U} / \mu \mathrm{l})$. The reactions were performed on a PTC 100 (MJ Research) using the following program: an initial denaturing step $\left(2 \mathrm{~min}\right.$ at $94^{\circ} \mathrm{C}$ ) followed by 35 cycles of the following steps: denaturing $\left(1 \mathrm{~min}\right.$ at $\left.95^{\circ} \mathrm{C}\right)$, annealing $(1 \mathrm{~min}$ at $55^{\circ} \mathrm{C}$ ) and extension $\left(1.30 \mathrm{~min}\right.$ at $\left.72^{\circ} \mathrm{C}\right)$; and a final extension step of $10 \mathrm{~min}$ at $72^{\circ} \mathrm{C}$. The PCR products were purified using the kit Concert ${ }^{\mathrm{m}}$ Rapid PCR Purification System (Life Technologies) before sequencing.

\section{DNA sequencing}

PCR products were sequenced using the procedure proposed by Sanger et al. [65]. Each sequence reaction contained: $2 \mu \mathrm{l}$ of Big Dye ${ }^{\mathrm{ma}}$ Terminator (Applied Biosystems), $1.5 \mu \mathrm{l}$ of PCR product $(5 \mathrm{ng} / \mu \mathrm{l}), 0.5 \mu \mathrm{l}$ of primer solution $(0.25 \mathrm{mM})$ and water up to $10 \mu \mathrm{l}$. The primers used on the sequencing reactions were the same used on the amplification of the target fragments. The sequencing reactions were performed on a PTC 100 (M.J. Research) using the following program: $1 \mathrm{~min}$ at $96^{\circ} \mathrm{C}, 40$ cycles of $10 \mathrm{sec}$ at $96^{\circ} \mathrm{C} ; 10 \mathrm{sec}$ at $55^{\circ} \mathrm{C} ; 4$ min at $60^{\circ} \mathrm{C}$. The sequencing was performed in an $\mathrm{ABI}$ PRISM 377 Automated DNA Sequencer (Perkin-Elmer/ Applied Biosystems). Each DNA strand was sequenced at least twice to ensure the accuracy of the results.

\section{Sequence and phylogenetic analysis}

The phylogenetic analysis was the Bayesian Inference with the MCMC calculations implemented by Mr. Bayes 3.1 [66]. The best evolution model $(G T R+G)$ was selected using mrmodeltest [67] and PAUP 4b10 [68]. The model parameters were set in the alignment nexus file and then ran in Mr. Bayes 3.1, which performed $20,000,000$ of generations, sampling trees in each 100 generations. The first 1250 trees were eliminated as the burn-in. The $50 \%$ majority consesus trees was inspected and prepared in figtree software.

\section{Acknowledgements \\ This work was funded by Fundação de Amparo à Pesquisa do Estado de São Paulo (FAPESP). JFMV, CRL, MAG thank CNPq for their fellowships.}

\footnotetext{
Author details

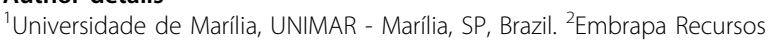
Genéticos e Biotecnologia, C.P. 02372, 70770-917, Brasília, DF, Brazil. ${ }^{3}$ Departamento de Ciências Biológicas, Faculdade de Ciências e Letras, UNESP - Universidade Estadual Paulista, 19806-900, Assis, SP, Brazil. ${ }^{4}$ Departamento de Genética, Instituto de Biociências, UNESP - Universidade Estadual Paulista, 18618-000, Botucatu, SP, Brazil. ${ }^{5}$ Departamento de
}

Bioquímica e Microbiologia, Instituto de Biociências, UNESP - Universidade Estadual Paulista, 13506-900, Rio Claro, SP, Brazil. ${ }^{6}$ Centro de Estudos de Insetos Sociais, Instituto de Biociências, UNESP - Universidade Estadual Paulista, 13506-900, Rio Claro, SP, Brasil.

\section{Authors' contributions}

All authors read and approved the final manuscript. MDB carried out the data collection and analysis and drafted the manuscript. MCM participated in the drafting of the manuscript. DAP and JPM participated in the sequencing and sequence analysis. MBJ and JMJ participated in the phylogenetic analysis. JFMV participated in the conception of the project and provided the germplasm. CRL and MAG participated in conceiving the study and analysis, and participated in drafting the manuscript.

Received: 12 February 2010 Accepted: 19 November 2010 Published: 19 November 2010

\section{References}

1. Krapovickas A, Gregory WC: Taxonomía del género Arachis (Leguminosae). Bonplandia 1994, 8:1-186.

2. Valls JFM, Simpson CE: New species of Arachis L. (Leguminosae) from Brazil, Paraguay and Bolivia. Bonplandia 2005, 14:35-64.

3. Krapovickas A: The origin, variability and spread of the peanut (Arachis hypogaea). In The domestication and exploitation of plants and animals. Edited by: Ucko J, Dimbleby C. Duckworth, London; 1969:427-440.

4. Gregory WC, Krapovickas A, Gregory MP: Structure, variation, evolution and classification in Arachis. In Advances in Legume Science. Edited by: Summerfiled RJ, Bunting AH. Kew: Royal Botanic Gardens; 1980:469-481.

5. Krapovickas A: A taxonomic summary of the genus Arachis. International Board for Plant Genetic Resources (IBPRG) - International Crop Network Series, 2. Report of a workshop on the genetic resources of wild species: Including preliminary descriptors for Arachis (IBPGR/ICRISAT) Rome, Italy. Appendix III 1990, 9.

6. Halward TM, Stalker HT, LaRue EA, Kochert G: Use of single primer DNA amplification in genetic studies of peanut. Plant Mol Biol 1992, 18:315-325.

7. Lanham PG, Forster BP, McNicol P, Moss JP, Powell W: Seed storage protein variation in Arachis species. Genome 1994, 37:487-496.

8. Singh AK, Gurtu S, Jambunathan R: Phylogenetic relationships in the genus Arachis based on seed protein profiles. Euphytica 1994, 74:219-225.

9. Lu J, Pickersgill B: Isozyme variation and species relationships in peanut and its wild relatives (Arachis L. - Leguminosae). Theor Appl Genet 1993, 85:550-560.

10. Stalker HT, Phillips TD, Murphy JP, Jones TM: Variation of isozyme patterns among Arachis species. Theor Appl Genet 1994, 87:746-755.

11. Jung S, Tate PL, Horn R, Kochert G, Moore K, Abbott AG: The Phylogenetic relationship of possible progenitors of the cultivated peanut. $J$ Hered 2003, 94:334-340.

12. Burow MD, Simpson CE, Faries W, Starr JL, Paterson AH: Molecular biogeography study of recently described B- and A-genome Arachis species, also providing new insights into the origins of cultivated peanut. Genome 2009, 52:107-119.

13. Moretzsohn MC, Hopkins MS, Mitchell SE, Kresovich S, Valls JFM, Ferreira ME: Genetic diversity of peanut (Arachis hypogaea L.) and its wild relatives based on the analysis of hypervariable regions of the genome. BMC Plant Biol 2004, 4:11.

14. Barkley NA, Dean RE, Pittman RN, Wang ML, Holbrook CC, Pederson GA: Genetic diversity of cultivated and wild-type peanuts evaluated with M13-tailed SSR markers and sequencing. Genet Res 2007, 89:93-106.

15. Gimenes MA, Hoshino AA, Barbosa AVG, Palmieri DA, Lopes CR: Characterization and transferability of microsatellite markers of the cultivated peanut (Arachis hypogaea). BMC Plant Biol 2007, 7:9.

16. Koppolu R, Upadhyaya HD, Dwivedi SL, Hoisington DA, Varshney RK: Genetic relationships among seven sections of genus Arachis studied by using SSR markers. BMC Plant Biol 2010, 10:15.

17. Milla SR, Isleib TG, Stalker HT: Taxonomic relationships among Arachis sect. Arachis species as revealed by AFLP markers. Genome 2005, 48:1-11.

18. Tallury SP, Hilu KW, Milla SR, Friend SA, Alsaghir M, Stalker HT, Quandt D: Genomic affinities in Arachis section Arachis (Fabaceae): molecular and cytogenetic evidence. Theor Appl Genet 2005, 111:1229-1237. 
19. Seijo GJ, Lavia Gl, Fernandez A, Krapovickas A, Ducasse D, Moscone EA: Physical mapping of the $5 \mathrm{~S}$ and $18 \mathrm{~S}-25 \mathrm{~S}$ rRNA genes by FISH as evidence that Arachis duranensis and A. ipaënsis are the wild diploid progenitors of $A$. hypogaea (Leguminosae). Am J Bot 2004, 91:1294-1303.

20. Robledo G, Lavia Gl, Seijo G: Species relations among wild Arachis species with the A genome as revealed by FISH mapping of rDNA loci and heterochromatin detection. Theor Appl Genet 2009, 118:1295-1307.

21. Robledo G, Seijo G: Species relationships among the wild $B$ genome of Arachis species (section Arachis) based on FISH mapping of rDNA loci and heterochromatin detection: a new proposal for genome arrangement. Theor Appl Genet 2010.

22. Wang CT, Wang XZ, Tang YY, Chen DX, Cui FG, Zhang JC, Yu SL: Phylogeny of Arachis based on internal transcribed spacer sequences. Genet Resour Crop Evol 2010.

23. Nóbile PM, Gimenes MA, Valls JFM, Lopes CR: Genetic variation within and among species of genus Arachis, section Rhizomatosae. Genet Resour Crop Evol 2004, 51:299-307.

24. Angelici CMLCD, Hoshino AA, Nóbile PM, Palmieri DA, Valls JFM, Gimenes MA, Lopes CR: Genetic diversity in section Rhizomatosae of the genus Arachis (Fabaceae) based on microsatellite markers. Genet Mol Biol 2008, 31:79-88.

25. Kochert G, Stalker HT, Gimenes MA, Galgaro L, Lopes CR, Moore K: RFLP and cytogenetic evidence on the origin and evolution of allotetraploid domesticated peanut Arachis hypogaea (Leguminosae). Am J Bot 1996, 83:1282-1291.

26. Fávero AP, Simpson CE, Valls FMJ, Velho NA: Study of evolution of cultivated peanut trough crossability studies among Arachis ipaënsis, $A$ duranensis and A hypogaea. Crop Sci 2006, 46:1546-1552.

27. Cunha FB, Nóbile PM, Hoshino AA, Moretzsohn MC, Lopes CR, Gimenes MA Genetic relationships among Arachis hypogaea L. (AABB) and diploid species with AA and BB genomes. Genet Resour Crop Evol 2008, 55:15-20.

28. Moretzsohn MC, Barbosa AVG, Alves-Freitas DMT, Teixeira C, LealBertioli SCM, Guimarães PM, Pereira RW, Lopes CR, Cavallari MM, Valls JFM, Bertioli DJ, Gimenes MA: A linkage map for the B-genome of Arachis (Fabaceae) and its synteny to the A-genome. BMC Plant Biol 2009, 9:40.

29. Lashermes $P$, Combes MC, Trouslot $P$, Charrier A: Phylogenetic relationships of coffee-tree species (Coffea L.) as inferred from ITS sequences of nuclear ribossomal DNA. Theor App/ Genet 1997, 94:947-955.

30. Lavin M, Thulin M, Labat JN, Pennington RT: Africa, the old man out: molecular biogeography of dalbergioid legumes (Fabaceae) suggests otherwise. Syst Bot 2000, 25:449-467.

31. Lavin M, Pennington RT, Klitgaard BB, Sprent Jl, Lima HC, Gasson PE: The dalbergioid legumes (Fabaceae): delimitation of a Pantropical monophyletic clade. Am J Bot 2001, 50:550-560.

32. Álvarez I, Wendel JF: Ribosomal ITS sequences and plant phylogenetic inference. Mol Phylogenet Evol 2003, 29:417-434.

33. Nieto Feliner $G$, Rosselló JA: Better the devil you know? Guidelines for insightful utilization of nrDNA ITS in species-level evolutionary studies in plants. Mol Phylogenet Evol 2007, 44:911-919.

34. Zhu X-Y, Cai D-T, Ding Y: Molecular and cytological characterization of 5 $S$ rDNA in Oryza species: genomic organization and phylogenetic implications. Genome 2008, 51:332-340.

35. Bayer RJ, Soltis DE, Soltis PS: Phylogenetic inferences in Antennaria (Asteraceae: Gnaphlilae: Cassiinae) based on sequences from nuclear ribossomal DNA internal transcribed spacers (ITS). Am J Bot 1996, 83:516-527.

36. Seijo G, Lavia Gl, Fernandez A, Krapovickas A, Ducasse DA, Bertioli DJ, Moscone EA: Genomic relationships between the cultivated peanut (Arachis hypogaea, Leguminosae) and its close relatives revealed by double GISH. Amer J Bot 2007, 94:1963-1971.

37. Gimenes MA, Lopes CR, Galgaro ML, Valls JFM, Kochert G: Genetic variation and phylogenetic relationships based on RAPD analysis in section Caulorrhizae, genus Arachis (Leguminosae). Euphytica 2000, 116:187-195.

38. Palmieri DA, Bechara MD, Curi RA, Monteiro JP, Valente SES, Gimenes MA, Lopes CR: Genetic diversity analysis in the section Caulorrhizae (genus Arachis) using microsatellite markers. Gen Mol Biol 2010, 33:109-118.

39. Fernández A, Krapovickas A: Cromosomas y evolución en Arachis (Leguminosae). Bonplandia 1994, 8:187-200.

40. Fávero AP: Caracterização morfológica, citogenética e molecular de acessos de germoplasma da espécie Arachis Kuhlmannii Krapov. \& W.C. Gregory (Secção Arachis). (Mestrado). UNESP: Botucatu; 1999, 159.
41. Raman VS: Studies in the genus Arachis. IV. Hybrid between A. hypogaea and A. monticola. Indian Oilseeds J 1958, 1:20-23.

42. Kochert G, Halward T, Branch WD, Simpson CE: RFLP variability in peanut (Arachis hypogaea L.) cultivars and wild species. Theor Appl Genet 1991, 81:565-570.

43. Raina SN, Mukai Y: Genomic in situ hybridization in Arachis (Fabaceae) identifies the diploid wild progenitors of cultivated (A. hypogaea) and related wild (A. monticola) peanut species. Plant Syst Evol 1999, 214:251-262.

44. Lavia Gl, Fernández A: Genome Size in wild and cultivated peanut germplasm. Pl Syst Evol 2008, 272:1-10.

45. Stalker HT: A new species in section Arachis of peanuts with a D genome. Am J Bot 1991, 78:630-637.

46. Lavia Gl, Ortíz AM, Fernández A: Karyotypic studies in wild germplasm of Arachis (Leguminosae). Genet Resour Crop Evol 2009, 56:755-764.

47. Lavia Gl: Estúdios cromosómicos en Arachis (Leguminosae). Bonplandia 1996, 9:111-120

48. Bravo JP, Hoshino AA, Angelici CMLCD, Lopes CR, Gimenes MA: Transferability and use of microsatellite markers for the genetic analysis of the germplasm of some Arachis section species of the genus Arachis. Genet Mol Biol 2006, 29:516-524.

49. Halward TM, Stalker HT, LaRue EA, Kochert G: Genetic variation detectable with molecular markers among unadapted germplasm resources of cultivated peanut and wild species. Genome 1991, 34:1013-1020.

50. Hilu KW, Stalker HT: Genetic relationships between peanut and wild species of Arachis sect. Arachis (Fabaceae): evidence from RAPDs. Plant Syst Evol 1995, 198:167-178.

51. Stalker HT: A morphological apprasial of wild species in section Arachis of peanuts. Peanut Sci 1990, 17:117-122.

52. Simpson CE, Faries MJ: Advances in the characterization of diversity in section Arachis: archeological evidence, crossing results and their relationship in the understanding the origins of Arachis hypogaea $\mathrm{L}$. Simpósio de Recursos Genéticos para a América Latina e Caribe: 19-22 November 2001. Londrina, Brazil Instituto Agronômico do Paraná; 2001 103-104

53. Singh AK, Moss JP: Utilization of wild relatives in the genetic improvement of Arachis hypogaea L 8. Synthetic amphidiploids and their importance in interspecific breeding. Theor Appl Genet 1986, 72:433-439.

54. Burow MD, Simpson CE, Starr JL, Paterson AH: Transmission genetics of chromatin from a synthetic amphidiploid to cultivated peanut (Arachis hypogaea L.): Broadening the gene pool of a monophyletic polyploid species. Genetics 2001, 159:823-837.

55. Gregory MP, Gregory WC: Exotic germ plasm of Arachis L. interspecific hybrids. J Hered 1979, 70:185-193.

56. Singh AK, Stalker HT, Moss JP: Cytogenetics and uses of alien genetic variation in groundnut improvement. In Chromosome Engineering in Plants: Genetics, Breeding, Evolution. Part B. Edited by: Tsuchiya T, Gupta PK Amsterdam: Elsevier Science Publishers; 1990:65-76.

57. Robledo G, Seijo G: Characterization of the Arachis (Leguminosae) D genome using fluorescence in situ hybridization (FISH) chromosome markers and total genome DNA hybridization. Genet Mol Biol 2008, 31:717-724.

58. Singh AK: Hybridization barriers among the species of Arachis L., namely of the sections Arachis (including the groundnut) and Erectoides. Genet Resour Crop Evol 1998, 45:41-45.

59. Valls JFM: Variability in the genus Arachis and potential forage uses. In Identifying Germplasm for Successful Forage Legume-Grass Interactions. Proceedings of a Symposium of the Crop Science Society of America. Edited by: Springer TL, Pittman RN. USDA, Washington; 1996:15-27.

60. Stalker HT, Dhesi JS, Kochert G: Variation within the species Arachis duranensis Krap \& W.C. Gregory, a possible progenitor of cultivated peanut. Genome 1995, 38:1201-1212.

61. Smartt J, Stalker HT: Speciation and cytogenetics in Arachis. In Peanut science and technology. Edited by: Pattee HE, Young CT. Yoakun: American Peanut Research Education Society; 1982:21-49.

62. Vander Stappen J, De Laet J, Gama-López S, Van Campenhout S, Volckaert G: Phylogenetic analysis of Stylosanthes (Fabaceae) based on the internal transcribed spacer region (ITS) of nuclear ribosomal DNA. Plant Syst Evol 2002, 234:27-51. 
63. Doyle JJ, Doyle JL: A rapid DNA isolation procedure for small quantities of fresh life tissue. Phytochem Bull 1987, 19:11-15.

64. White TJ, Bruns TD, Lee SB, Taylor JW: Amplification and direct sequencing of fungal ribosomal RNA genes for phylogenetics. In $P C R$ Protocols: A Guide to Methods and Applications. Edited by: Innis M, Gelfand D, Sninsky J, White T. San Diego: Academic Press; 1990:315-322.

65. Sanger F, Nicklen S, Coulson AR: DNA sequencing with chain-terminating inhibitors. Proc Natl Acad Sci USA 1977, 74:5463-5468.

66. Huelsenbeck JP, Ronquist F: MRBAYES: Bayesian inference of phylogeny. Bioinformatics 2001, 17:754-755.

67. Nylander JAA: MrModeltest v2. Program distributed by the author Evolutionary Biology Centre, Uppsala University; 2004.

68. Swofford DL: PAUP* Phylogenetic analysis using parsimony (*and other methods), v 4b10. Sinauer Sunderland; 2002.

69. Valls JFM, Simpson CE: Taxonomy, natural distribution, and attributes of Arachis. In Biology and Agronomy of Forage Arachis. Edited by: Kerridge PC Hardy B. Cali: CIAT; 1994:1-18.

70. Lavia G, Fernández A, Seijo J: Cytogenetic and molecular evidences on the evolutionary relationships among Arachis species. In Plant Genome: Biodiversity and Evolution, Phanerogams-Angiosperm. Volume 1E. Edited by: Sharma A. Enfield, NH: Science Publishers; 2008:101-134.

doi:10.1186/1471-2229-10-255

Cite this article as: Bechara et al:: Phylogenetic relationships in genus Arachis based on ITS and 5.8S rDNA sequences. BMC Plant Biology 2010 10:255.

\section{Submit your next manuscript to BioMed Central} and take full advantage of:

- Convenient online submission

- Thorough peer review

- No space constraints or color figure charges

- Immediate publication on acceptance

- Inclusion in PubMed, CAS, Scopus and Google Scholar

- Research which is freely available for redistribution

Submit your manuscript at www.biomedcentral.com/submit 